\title{
Study on the green total factor productivity in main cities of China ${ }^{* 1}$
}

\author{
Zhang Jiansheng ${ }^{2}$, Tan Wei
}

\begin{abstract}
The aim of this research is to investigate China's urban green total factor productivity (TFP) under the background of progressing urbanization and intensifying environmental pollution, and found out its main influencing factors. In this paper, green TFP of 285 prefecture-level cities in China from 2005 to 2012 was estimated through Malmquist productivity index. Results showed that the annual growth of green TFP in main cities in China is 3.5\% and the overall growth declines gradually. Viewed from decomposition of green TFP, technical progress is the main contributor of green TFP growth. Furthermore, the northern coastal region has achieved the highest annual growth of green TFP (4.5\%) and the northwest region achieved the lowest growth of green TFP (1.24\%), indicating the great regional differences of green TFP and economic growth quality in China. According to analysis on influencing factors of green TFP in main cities, it has been concluded that per-capita urban road area, number of Internet users, proportion of fiscal expenditures, environmental regulation level and technical input are significantly positively correlated with green TFP, while industrial structure and foreign direct investment (FDI) are significantly negatively correlated. Finally, policy suggestions to improve urban green TFP in China were proposed.
\end{abstract}

Key words: green total factor productivity, Malmquist-Luenberger productivity index, directional distance function, China

JEL classification: $013,018, Q 56$

\footnotetext{
* Received: 17-03-2016; accepted: 17-06-2016

1 This work is supported by National Social Science Foundation of China (No. 12XGL019).

2 Associate Professor, College of Finance and Economics, Chongqing Three Gorges University, Chongqing 404120, China. Scientific affiliation: development economics, industrial policies. Phone: +861592340 0592. E-mail: asheng0124@126.com (Corresponding author).

3 Associate Professor, College of Public Management, Chongqing Three Gorges University, Chongqing 404120, China. Scientific affiliation: industrial policies. Phone: +8615826405802. E-mail: tanwei0524@126.com.
} 


\section{Introduction}

China has achieved rapid economic development in the past 3 decades after the reform and opening-up policy, ranking the second in term of economic aggregate. However, such rapid economic development brings intensifying environmental pollution. Due to frequent "haze" in most cities in China, the academic circles pay more and more attention to the relationship between environment and economic growth in recent years. As a developing country, China shall focus on how to facilitate sustainable economic development at present and in the future. The economic growth theory and practices show that increasing input of production factors (e.g. labor and capital) and total factor productivity (TFP) can promote economic growth. But only increasing TFP is the key of promoting sustainable economic growth. Therefore, deep analysis of China's TFP growth and growth source of green TFP under environmental constraints has important significance to relieve the contradiction between economic growth and environmental pollution.

As China' urbanization progresses continuously, city is becoming the basic regional unit for a region to participate in market competition and market division. It plays an extremely important role in regional economic development and growth. However, when China's urbanization facilitates rapid economic and social development, it also concentrates massive population and economic activities and causes a series of serious ecological environmental problems, such as water shortage, atmosphere pollution, etc. How to achieve the balance between economic benefit and ecological benefit has been a big challenge for China's urban development.

Existing research has pointed out that China's urban economic efficiency is still in the preliminary research period while previous researchers didn't include environmental effect into estimation of urban TFP. Considering shortages of previous researchers, this paper has studied two aspects. Firstly, it has attempted to include environmental factors into the analysis framework of urban TFP and measured urban TFP growths in China by giving comprehensive considerations to GDP growth and reduction of pollutant discharges. Secondly, it has made an empirical study on main influencing factors. To solve these two problems, it has put forward a basic hypothesis that urban TFP in China when considering environmental factors is lower than that neglecting environmental factors. Human capital, urban infrastructure construction, fiscal expenditure, environmental regulation level, technical input, economic density, industrial structure and FDI are important influencing factors of urban green TFP.

In this paper, the presentation of the issue is organized as follows: section 2 is literature review, section 3 introduces research methods, section 4 comprises data specification, section 5 is empirical analysis, and the final section 6 consists of conclusions. 


\section{Literature review}

Traditional TFP estimation only considers market economic indexes such as GDP, but neglects bad outputs (e.g. waste gas and waste water) that will influence environmental pollution, thus resulting in evaluation distortion of social welfare changes and economic performance. Many scholars began to consider influences of 'bad' outputs in recent years and tried to integrate environmental factors in the analysis framework of efficiency and productivity. When measuring TFP of pulp mill in Sweden, Chung et al.(1997) introduced a new function -----directional distance function (DDF) and proposed the Malmquist-Luenberger (ML) productivity index which could measure TFP when there are 'bad' outputs (e.g. waste gas and waste water). The ML productivity index takes both increases of 'good' outputs and reduction of 'bad' outputs into account and possesses all goods properties of Malmquist productivity index (Wang Bing and Wang Li, 2010). Estimation of green TFP has been one of research hotspots in the economic circle in the past years.

At present, TFP researchers in China focus on two aspects. On one hand, some tested economic productivity of agriculture, industry and service industry, but they left environmental factors out of consideration. Based on data from 19982009, Yang Rudai (2015) investigated dynamic changes of TFP of manufacturing enterprises in China, finding out that the overall TFP growth rate in China's manufacture industry ranged between $2 \%-3 \%$ and the annual growth was $3.83 \%$. Enterprises of different ownerships had significantly different efficiencies. Investment efficiency of state-owned enterprises was $43 \%$ lower than that of private enterprises. In the productivity measurement of agriculture and service industry field, some scholars have been included in studies. Pan Dan (2012) analyzed spatial and temporal variation characteristics of China's agricultural TFP by using data from 1978-2008 and believed that the annual growth rate of China's agricultural TFP was 3.17\%. Yuan Dan and Lei Hongzhen (2015) used Malmquist productivity index and analyzed heterogeneity of TFP of producer services in China from 2004 2011 from three perspectives: industry, time and region. They made a convergence test on its trend, finding that the overall TFP of producer services reduced $1.9 \%$ every year in average. On the other hand, some researches integrated environmental factors into the analysis framework of TFP and studied sectional or regional TFP under environmental constraints. Xue Jianliang and Li Binlong (2011) calculated volume of main agricultural pollutant discharges in China from 1990-2008 by the unit-based comprehensive survey evaluation. On this basis, they measured China's agricultural TFP based on environmental correction. They pointed out that from 1990-2008, agricultural productivity growth after China adjusted the economic environment reduced gradually and agricultural pollution decreases agricultural productivity growth by $0.09 \%-0.6 \%$. Unlike Jian Liang Xue and Bing Long Li (2011), Kuang Yuan Feng and Daiyan Peng (2012) estimated 
the efficiency of China's environmental production from the perspective of regional. Xiao Sheng Li and Qing Xian an (2012) calculated the green total factor productivity of industry in China. For example, Kuang Yuanfeng and Peng Daiyan (2012) studied China's productivity under environmental constraints and TFP growth from 1995-2009. They reported that compared to traditional productivity, environmental productivity could reflect productivity loss caused by environmental issues and provincial difference in resource utilization. Based on 362 bits industrial input and output data of China's industry from 1998-2010, Li Xiaosheng and An Qingxian (2012) discussed environmental regulation cost and green TFP by using directional distance function and ML index. They found that China's industry claimed high environmental regulation cost and green TFP increased generally, which was mainly attributed to technical progress.

Although more and more researchers have applied Malmquist-Luenberger productivity index to estimate China's green TFP, they have not estimated yet the urban TFP in China under environmental constraints. Therefore, this paper employed ML productivity index to estimate urban TFP in China and analyzed its influencing factors.

\section{Methodology}

\subsection{The Malmquist Luenberger (ML) productivity index}

The directional distance function (DDF) not only encourages the desired outputs to the expansion of production frontier, but also encourages the pollution emissions to the minimization of pollution. So it conforms to the concept of the sustainable development. Based on this, this paper will measure China's urban green total factor productivity by the methods of DDF and Malmquist Luenberger (ML) productivity index.

Since this paper mainly focused on measurement of urban environmental economic growth, city was used as the decisive unit. Suppose cities use $N$ kinds of inputs $X=\left(x_{1}, x_{2}, \ldots, x_{N}\right) \in \mathrm{R}_{+}^{N}$ and produce $M$ kinds of 'goods' outputs $Y=\left(y_{1}, y_{2}, \ldots, y_{M}\right) \in \mathrm{R}_{+}^{M}$ as well as I kinds of 'bad' outputs $U=\left(u_{1}, u_{2}, \ldots, u_{I}\right) \in \mathrm{R}_{+}^{I}$. According to the study of Fare et al. (2007), the production possibility set of environmental technology is:

$$
T=\left[(x, y, u):\left(y, u \in P(x), x \in \mathrm{R}_{+}^{N}\right)\right]
$$

The production possibility set $p(x)$ is a bounded closed set and has following characteristics (Wu Jun, 2009):

1) The jointly weak disposability between 'good' outputs and 'bad' outputs. If $(y, u) \in p(x)$ and $0 \leq \theta \leq 1,(\theta y, \theta u) \in p(x)$. This indicates that given a fixed input level, 'good' outputs shall reduce accordingly when 'bad'outputs decreases. 
2) Strong or free disposability between inputs and 'goods' outputs. If $x^{\prime} \leq x$, $p\left(x^{\prime}\right) \subseteq p(x)$. If $(y, u) \in p(x)$ and $y^{\prime} \leq y,\left(y^{\prime}, u\right) \in p(x)$. This means that 'goods' outputs can be controlled freely, but 'bad' outputs is kept same.

3) Null-jointness between 'goods' outputs and 'bad' outputs. If $(y, u) \in p(x)$ and $b=0, y=0$. This implies that 'goods' outputs are accompanied with 'bads' outputs. According to the study of Fare et al., $p(x)$ meets null-jointness as well as the following two conditions:

$$
\begin{aligned}
& \sum_{i=1}^{K} u_{k i} \succ 0, i=1, \ldots, I \\
& \sum_{i=1}^{I} u_{k i} \succ 0, k=1, \ldots, K
\end{aligned}
$$

Equation (2) represents that at least one production unit is producing one 'bad' output and Equation (3) represents every production unit generates at least one 'bad' output.

The Environmental technology provides the production possibility set, which is foundation of estimating the green total factor productivity. Thus, each city can be regarded as a decision making unit, the directional distance function can calculate the relative efficiency of each decision making unit.

Directional distance function represents the possibility of proportional reduction of 'bad' outputs against increase of 'good' outputs when direction $g=\left(g_{y},-g_{b}\right)$, input $x$ and production possibility set $p(x)$ are fixed. It is defined as (Chambers et al., 1996; Fare et al., 2005):

$$
\overrightarrow{D_{0}^{t}}\left(x^{t}, y^{t}, u^{t} ; g_{y},-g_{u}\right)=\sup \left[\beta:\left(y^{t}+\beta g_{y}, u^{t}-\beta g_{u}\right) \in p^{t}\left(x^{t}\right)\right]
$$

Equation (4) is the directional distance function in $t$. It compares $\left(y^{t}, u^{t}\right)$ and production leading edges in $t$. In other words, $g=\left(g_{y},-g_{u}\right)$ is the direction vector of the current directional distance function. Actually, the output distance function of Shephard is a special condition of directional distance function. Relation between these two distance functions is:

$$
\overrightarrow{D_{0}}\left(x^{t}, y^{t}, u^{t} ; g^{t}\right)=\left(1 / D^{t}\left(x^{t}, y^{t}, u^{t}\right)\right)-1
$$

The directional distance function of production unit $k^{\prime}\left(x_{k}^{t}, y_{k}^{t}, u_{k}^{t}\right)$ in $\mathrm{t}$ can be converted into linear programming solution through data envelopment analysis (Fare, et al.1994): 


$$
\begin{aligned}
& \overrightarrow{D_{0}^{t}}\left(x_{k^{\prime}}^{t}, y_{k^{\prime}}^{t}, u_{k^{\prime}}^{t} ; y_{k^{\prime}}^{t},-u_{k^{\prime}}^{t}\right)=\max \beta \\
& \text { s.t. } \sum_{k=1}^{K} z_{k}^{t} y_{k m}^{t} \geq(1+\beta) y_{k^{\prime} m}^{t}, m=1, \ldots, M \\
& \sum_{k=1}^{K} z_{k}^{t} u_{k i}^{t}=(1-\beta) u_{k^{\prime} i^{\prime}}^{t}, i=1, \ldots, I \\
& \sum_{k=1}^{K} z_{k}^{t} x_{k n}^{t} \leq x_{k^{\prime} n}^{t}, n=1, \ldots, N ; z_{k}^{t} \geq 0 ; k=1, \ldots, K
\end{aligned}
$$

Based on the directional distance function, according to the study of Chung et al. (1997), ML productivity index from $t$ to $t+1$ is (Fare, et al., 2007):

$$
M L_{t}^{t+1}=\left[\frac{1+\overrightarrow{D_{0}^{t}}\left(x^{t}, y^{t}, u^{t} ; y^{t},-u^{t}\right)}{1+\overrightarrow{D_{0}^{t}}\left(x^{t+1}, y^{t+1}, u^{t+1} ; y^{t+1},-u^{t+1}\right)} \times \frac{1+\overrightarrow{D_{0}^{t+1}}\left(x^{t}, y^{t}, u^{t} ; y^{t},-u^{t}\right)}{1+\overrightarrow{D_{0}^{t+1}}\left(x^{t+1}, y^{t+1}, u^{t+1} ; y^{t+1},-u^{t+1}\right)}\right]^{1 / 2}
$$

If the Malmquist Luenberger (ML) productivity index is higher than 1, the productivity increases from $t$ to $t+1$; otherwise, it decreases.

The Malmquist Luenberger (ML) productivity index is further decomposed into efficiency change (MLEFFCH) and technical progress (MLTECH):

$$
\begin{aligned}
& M L_{t}^{t+1}=\text { MLEFFCH }_{t}^{t+1} \times \text { MLTECH }_{t}^{t+1} \\
& \operatorname{MLEFFCH}_{t}^{t+1}=\frac{1+\overrightarrow{D_{0}^{t}}\left(x^{t}, y^{t}, u^{t} ; y^{t},-u^{t}\right)}{1+\overrightarrow{D_{0}^{t+1}}\left(x^{t+1}, y^{t+1}, u^{t+1} ; y^{t+1},-u^{t+1}\right)}
\end{aligned}
$$

$\operatorname{MLTECH}_{t}^{t+1}=\sqrt{\frac{1+\overrightarrow{D_{0}^{t+1}}\left(x^{t}, y^{t}, u^{t} ; y^{t},-u^{t}\right)}{1+\overrightarrow{D_{0}^{t}}\left(x^{t}, y^{t}, u^{t} ; y^{t},-u^{t}\right)} \times \frac{1+\overrightarrow{D_{0}^{t+1}}\left(x^{t+1}, y^{t+1}, u^{t+1} ; y^{t+1},-u^{t+1}\right)}{1+\overrightarrow{D_{0}^{t}}\left(x^{t+1}, y^{t+1}, u^{t+1} ; y^{t+1},-u^{t+1}\right)}}$

If MLEFFCH $>1$, the decisive unit efficiency increases gradually; otherwise, the decisive unit declines gradually. MLTECH $>1$ represents the decisive unit produces technical progress; otherwise, it causes technical retrogress (Wu Jun, 2009; Jiansheng Zhang et al., 2014).

\subsection{Introduction to indexes}

The choice of input and output indicators is very important for the estimation of total factor productivity. The input and output indicators in this paper not only consider the data acquisition, but also consider the representation. 
Input indexes: capital input and labor input are used to calculate TFP. Since China's existing statistical data only gives fixed asset input, capital stocks of prefecturelevel cities were calculated through "perpetual inventory method" in this paper: $K_{i t}=K_{i t-1}(1-\delta)+I_{i t} / P_{i t}$, where I is annual fixed assets input, $P$ is price index of fixed assets input and $\delta$ is rate of depreciation. According to research results of Zhong Youhui (2015), $\delta$ was determined 9.6\%. With respect to the capital stock of the base year, the total fixed assets inputs in 2005 divided by $10 \%$ was taken as the initial capital stock. To eliminate influences of price, price indexes of investment in fixed assets of provinces of the city were converted into constant price in 2000, which were viewed as the final calculated results.

Output index: 'good' outputs are expressed by GDP of cities. Similarly, to make data comparable, nominal GDP of prefecture-level cities is the constant price in 2000 converted from the provincial GDP deflator. Eliminate price influences and the actual GDP could be gained. 'bad'outputs are expressed by industrial $\mathrm{SO}_{2}$ discharge of cities.

\subsection{Selection of influencing factors of green TFP}

Based on existing researches, this section discussed the influencing factors of green TFP from multiple perspectives. Selection of the influencing factors considered factors that may influence traditional TFP and factors caused by environmental regulation. There were many other factors to choose, for example, a number of institutional factors. However, we cannot get the relevant data of a lot of factors . According to the research results of Bing Wang et al. (2011), this paper chose the following 8 variables:

1) Human capital (hum). Accumulation of Hum could bring incremental benefits and incremental benefits of other input elements. It will cause overflow effect to economic growth. Hum can facilitate input-output efficiency and TFP growth.

2) Infrastructure (ins). Infrastructure like traffic and communication are important decisive factors of economic growth. Infrastructure improvement (Branchi et al., 2015), on one hand, is beneficial to enhance commodities and population flows between regions, thus accelerating spreading of knowledge and technologies. It plays an important role in TFP growth. On the other hand, infrastructure improvement can promote reduction of transportation cost and transaction cost effectively, as well as to optimize resources allocation and increase economic efficiency.

3) Foreign direct investment (FDI). FDI plays an important role in China's economic growth in the past 3 decades. Particularly, it made great contributions to China's employment and local government tax revenues. According to the technology spillover theory, FDI will surely cause technology spillover to host country because it brings production technology and management level of more 
advanced countries. As a result, it will facilitate technical progress and increase technical efficiency of enterprises in the host country. In addition, FDI can reflect the opening level of a city.

4) Industrial structure (str). For a city, industrial structure can reflect its economic structure and development pattern (Wang and Hsu, 2014). Followers of sstructuralism have deemed that evolution of industrial structure is actually a process of input elements shifting from low-efficiency sectors to high-efficiency sectors to realize the "structural bonus". Industrial structure change is one of the core driving forces of economic growth and ensure the sustainable economic growth.

5) Proportion of fiscal expenditure (fis). Government expenditure scale can reflects degree of city government intervention on economy and public service supply capacity of a city government. Proportion of fiscal expenditure could influence infrastructure construction, education development and other aspects of one city or region significantly, further influencing the regional economic growth. Besides, to achieve economic benefits (e.g. tax revenue growth) and political interests (e.g. promotion, political future and popularity), government decision makers prefer the "catching-up" development strategy. In other words, they formulate tax preference, development subsidy, loan subsidy and other fiscal policies in favourable of high-tech equipment enterprises, thus enabling these enterprises to achieve technical progress. Such technical progress will surely generate overspill effect to low-tech equipment enterprises, finally realizing the overall technical progress of the city of the region. Nevertheless, government intervention may distort the element price system, lower capital efficiency and cause social welfare losses (Zhu Hongwei et al., 2013). Therefore, whether government intervention could promote economic performance is determined by comparison of its positive and negative impacts.

6) Technical input (tec). According to the endogenous growth theory, R\&D activity can not only drive technical innovation of the department, but also cause technical overspill to increase public knowledge stock (Wu et al., 2016), finally facilitating the overall social and economic growth and TFP growth. Early researches made by Chinese scholars put forward three main opinions: 1) R\&D input has significantly positive impact on TFP; 2) R\&D input is negative to TFP growth or it couldn't prove the positive relation between them; 3) effect of R\&D input on TFP differs because of difference of the subject.

7) Economic density (eco). Economic density refers to the regional GDP/national territorial area. It can reflect not only economic activity loads per unit land area and land utilization of a city, but also economic activity scale of a city. Theoretically, higher economic density is more beneficial for technology generalization, thus enabling generate higher knowledge overspill effect and bring significant external economy. 
8) Environmental regulation level (env). Environmental regulation means that since abundant pollutant discharges cause unsustainable social and economic growths, government adopts compulsory measures like administrative penalty, taxation and pollutants discharge license to control production activities of enterprises, aiming to achieve harmonious development between environment and economy. During early economic development after the reform and opening-up policy, Chinese government had relatively limited environmental regulation measures, but environmental pollution caused by long-term extensive growth intensified increasingly. For this reason, government adopted higher and higher environmental regulation and researches on TFP under environmental regulation increased gradually.

Due to different explanatory variables may cause different degrees of delayed influences to TFP and TFP is based on growth of last year, so this part took the accumulated TFP as the explained variable. Due to the dynamic analysis of total factor productivity, and the research conducted by Managi and Ranjan (2008), Bing Wang et al. (2011), the total factor productivity was converted to 1+TFP, then gave logarithmic. Based on analysis of above mentioned explanatory variables, an urban TFP decision model under environmental constraint was established (all variables applied logarithmic forms in order to eliminate heteroscedasticity of every variable).

\section{Empirical data and analysis}

\subsection{Data sources}

Sample data used in this paper were collected from China City Statistical Yearbook and China Statistical Yearbook from 2005 to 2012, involving 285 prefecturelevel cities. Few missing index data were replaced by means of the past three years. Considering data availability, Human capital of cities was expressed by college students $(/ 10,000)$ in this paper. Transportation infrastructure is expressed by per-capita urban road area and communication infrastructure is expressed by international Internet users $(/ 10,000)$. "Road" expresses transportation infrastructure, "Int" expresses communication infrastructure. Due to the big difference of economic scale and FDI size between cities, FDI was expressed by FDI/GDP in this paper. The proportion of value added of the secondary industry in GDP was used to express industrial structure here. Proportion of fiscal expenditure was expressed by proportion of government expenditure in GDP. Technical input was expressed by proportion of R\&D input in fiscal expenditure. Since industry is the main cause of urban pollution, Economic density was expressed by gross industrial output per square kilometers. Economic density is expected to be proportional to TFP. Environmental regulation level was expressed by $\mathrm{SO}_{2}$ removal rate. It could reflect governments' attentions and management capacity on pollutant discharges. It is expected to be proportional to TFP. 


\subsection{Descriptive statistics}

Figure 1 describes the data of related variables in 285 city of China. It can be seen that the numbers of urban GDP and capital in China are growing rapidly. The average annual growth rate of urban and capital respectively is $12.83 \%$ and $7.82 \%$. There has also been a rapid increasing in the total number of urban employees, from 185 million in 2005 to 276 million in 2012. The average number of employees in each city grew from 649.5 thousand in 2005 to 930.2 thousand in 2012. The emissions of sulfur dioxide have been slow down and the emissions are 70.4 thousand ton in 2005 to 59.8 thousand ton in 2012. It shows that the "emission reduction" measures taken by the Chinese government in recent years have gradually produced good results.

Figure 1: Changes in input and output variables

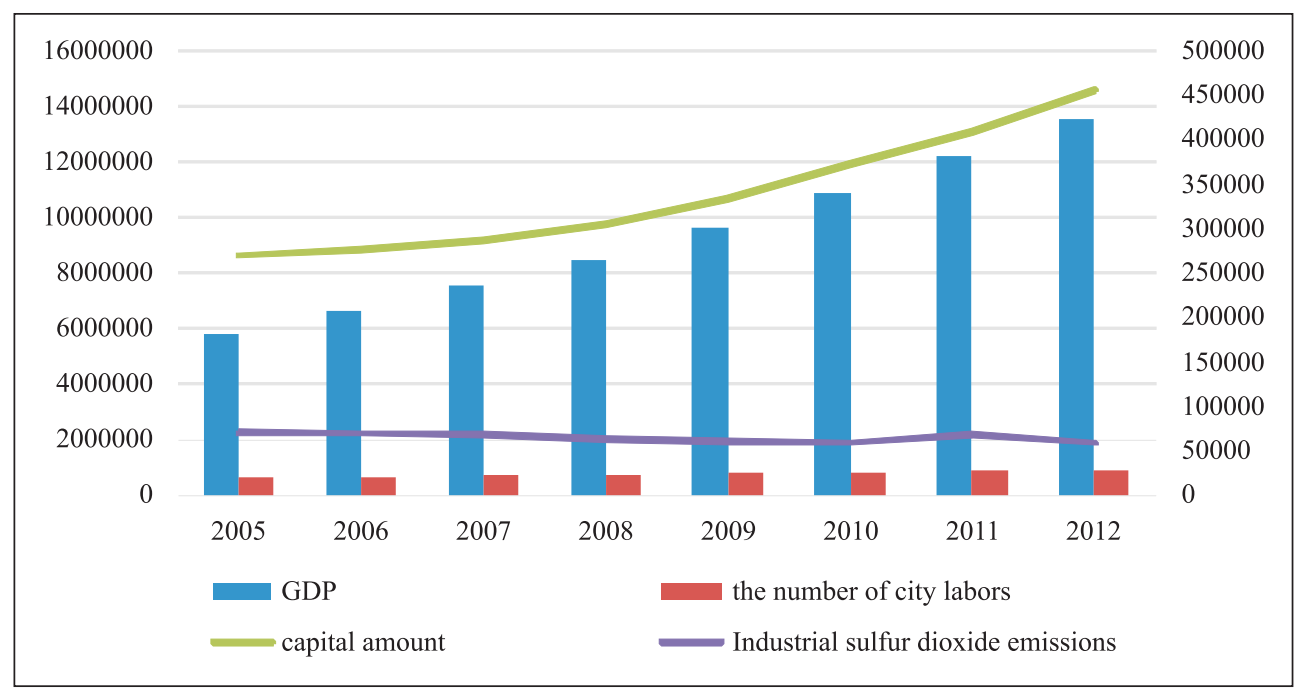

Source: Authors' calculation

Table 1 describes the changes of influencing factors on green TFP. 
Zhang Jiansheng, Tan Wei $\bullet$ Study on the green total factor productivity in main cities...

Table 1: The average value of influencing factors

\begin{tabular}{|l|r|r|r|r|r|r|r|r|}
\hline $\begin{array}{l}\text { Influencing } \\
\text { factors }\end{array}$ & 2005 & 2006 & 2007 & 2008 & 2009 & 2010 & 2011 & 2012 \\
\hline Human capital & 117 & 126 & 138 & 146 & 158 & 223 & 168 & 172 \\
\hline $\begin{array}{l}\text { Transportation } \\
\text { infrastructure }\end{array}$ & 7.79 & 8.59 & 9.18 & 9.48 & 9.8 & 10.63 & 11.30 & 12.29 \\
\hline $\begin{array}{l}\text { Communication } \\
\text { infrastructure }\end{array}$ & 565 & 594 & 672 & 780 & 973 & 1353 & 1328 & 1499 \\
\hline FDI & 2.23 & 2.26 & 2.12 & 1.99 & 1.93 & 1.84 & 1.86 & 1.87 \\
\hline Industrial structure & 46.12 & 47.8 & 49.05 & 50.07 & 49.30 & 50.88 & 52.02 & 51.45 \\
\hline $\begin{array}{l}\text { Proportion of fiscal } \\
\text { expenditure }\end{array}$ & 11.91 & 12.97 & 14.33 & 16.44 & 17.33 & 16.02 & 18.24 & 19.01 \\
\hline Technical input & 1.28 & 1.27 & 1.27 & 1.31 & 1.32 & 1.33 & 1.48 & 1.49 \\
\hline Economic density & 1300 & 1630 & 2040 & 2480 & 2649 & 3365 & 3950 & 4302 \\
\hline $\begin{array}{l}\text { Environmental } \\
\text { regulation level }\end{array}$ & 22.93 & 26.66 & 32.21 & 37.21 & 43.80 & 44.52 & 48.01 & 49.68 \\
\hline
\end{tabular}

Source: Authors' calculation

In general, FDI share of GDP is constantly decreasing, the annual decline of $2.43 \%$. The average annual growth of capital and infrastructure respectively is $7.15 \%$ and $6.76 \%$. The growth rate of communication infrastructure is the fastest, as $15.59 \%$. The growth rate of technical structure and industrial input is slow, and the average annual growth rate of only $1.63 \%$ and $2.26 \%$. It shows the economic growth in China is still dependent on the rapid expansion of the industry, while in the economic growth process, $\mathrm{R} \& \mathrm{D}$ investment is insufficient, and innovative ability is not strong. Meanwhile, the proportion of fiscal expenditure, the average annual growth rate is $7.14 \%$. And the growth rate of environmental regulation level is $11.87 \%$. The growth rate of economic density is the fastest-growing, while the average annual is $18.89 \%$.

\section{Results and discussion}

This paper above has analysized the whole changes of green TFP in 285 Chinese cities. Due to the different parts of China have great differences in such aspects as economic development, natural environment, so this part compared the green TFP in different cities of eight regions in China. And the influencing factors of green TFP were given the regression analysis by GMM and panel data. 


\subsection{Calculated results of green TFP}

According to above analysis, green TFP of 285 cities was estimated. Results were analyzed in the following text.

Geometric mean variations of green TFP of 285 prefecture-level cities from 20062012 are shown in Figure 2.

Figure 2: Urban green TFP and its decomposition

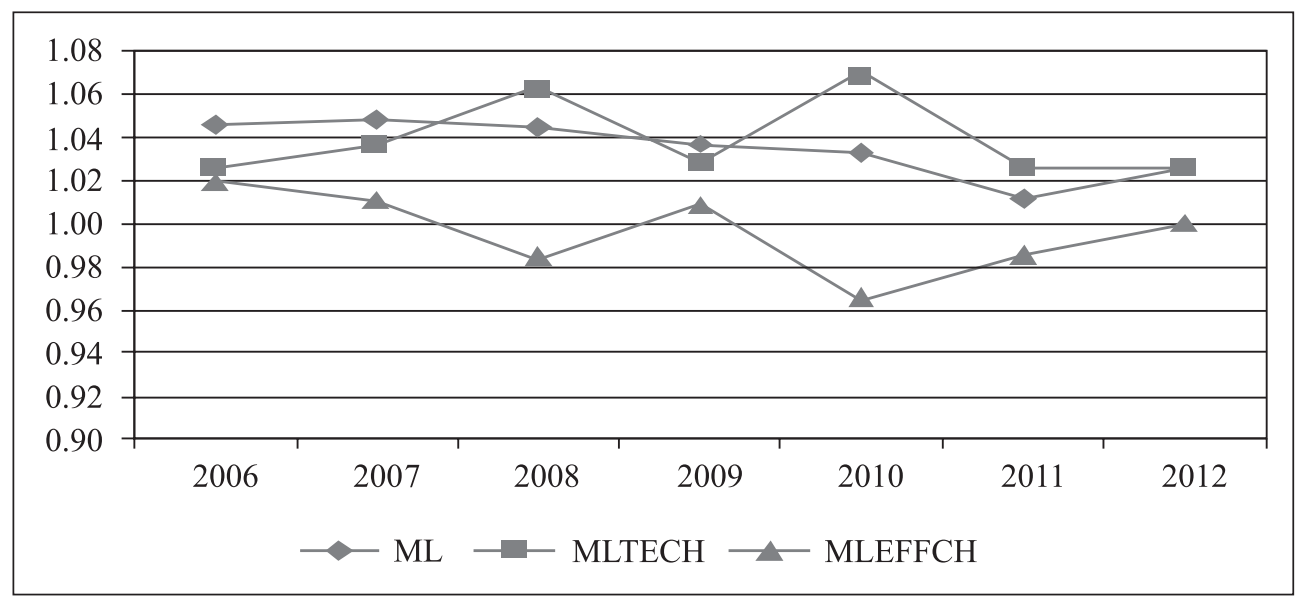

Source: Authors' calculation

Green TFP growth was $4.60 \%$ in 2006 and reached the peak (4.81\%) in 2007. Subsequently, it declined gradually and decreased to $1.17 \%$ in 2011 . The green TFP growth in 2012 increased slightly, valuing $2.65 \%$. The urban green TFP declined generally from 2006-2012.

Viewed from decomposition of green TFP, technical progress is the main contributor of green TFP growth. The highest technical progress rate was $7.1 \%$ in 2010 and the lowest was $2.6 \%$ in 2011 and 2012. From 2006-2012, technical efficiency declined in three years and the maximum reduction reached as high as $-3.53 \%$. The highest growth rate of technical efficiency was only $1.95 \%$.

\subsection{Comparison of 8 regions}

Green TFP variations of 8 regions are shown in Figure 3. The northern coastal region achieved the highest annual average growth of green TFP (4.5\%), followed by eastern coastal region $(4.41 \%)$, northeast China $(3.98 \%)$, southern coastal region $(3.80 \%)$, southwest China (3.64\%), the middle reach of the Yangtze River $(3.44 \%)$, the midstream of the Yellow River (2.85\%) and northwest China (1.24\%) successively. 
Figure 3: Green TFP variations in main cities of 8 regions

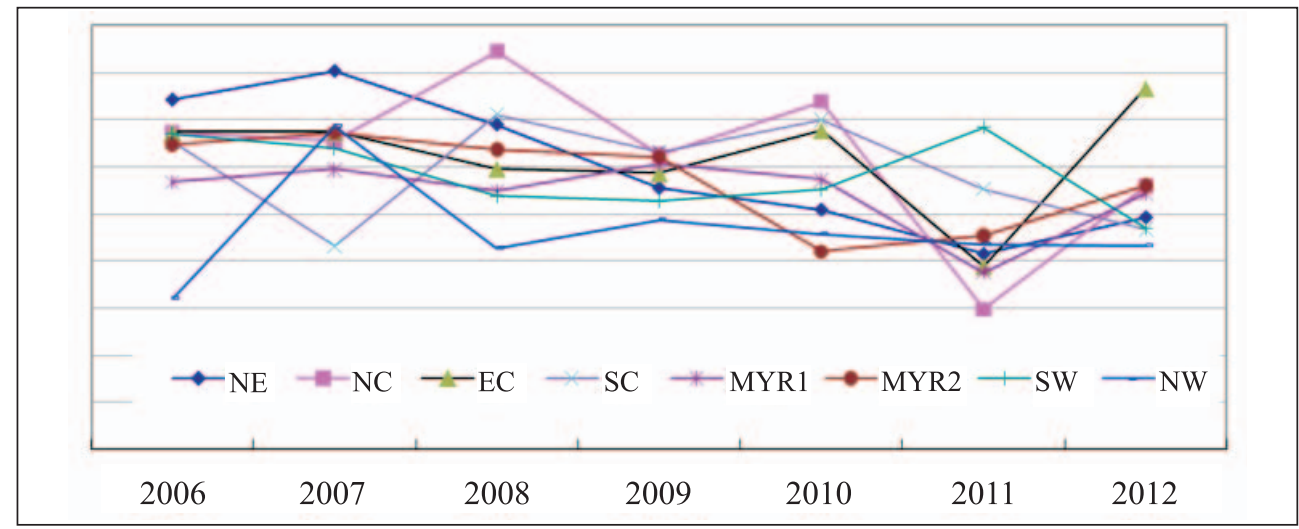

Note: NE, NC, EC, SC, MYR1, MYR2, SW and NW represent northeast China, northern coastal region, eastern coastal region, southern coastal region, the midstream of the Yellow River, the middle reach of the Yangtze River, southwest and northwest China.

Source: Authors' calculation

Viewed from variation trends, within the period from 2006 to 2012, green TFP of northeast China, southern coastal region, the middle reach of the Yangtze River, southwest China and northwest China dropped significantly, while green TFP of the eastern coastal region, northern coastal region and the midstream of the Yellow River decreased slightly. In the eastern coastal region, green TFP dropped significantly in 2011, but the annual growths in 2010 and 2012 were $5.52 \%$ and $7.31 \%$, respectively, higher than that from 2006-2009. This reflects great regional differences in green TFP and economic growth quality in recent years.

Technical progress changes of 8 regions under environmental constraints are presented in Figure 4. These 8 regions were ranked from eastern coastal region (5.37\%), northern coastal region (5.32\%), southern coastal region (4.63\%), the middle reach of the Yangtze River (4.34\%), northeast China (4.17\%), southwest China (3.27\%), the midstream of the Yellow River (2.62\%) to northwest China $(2.36 \%)$. The annual average technical progress rate in the eastern coastal region and the northern coastal region changed the least, while that in the northwest region changed the most violently. Technical progress rate of the northwest region differed significantly in different years, reaching the peak (7.47\%) in 2010 and lowest $(-1.32 \%)$ in 2006 . On the whole, technical progress rate of 8 regions reached the peak in 2008, but it declined greatly in 2009 due to the financial crisis. In 2010, technical progress rate increased gradually again. 
Figure 4: Technical progress changes of 8 regions under environmental constraints

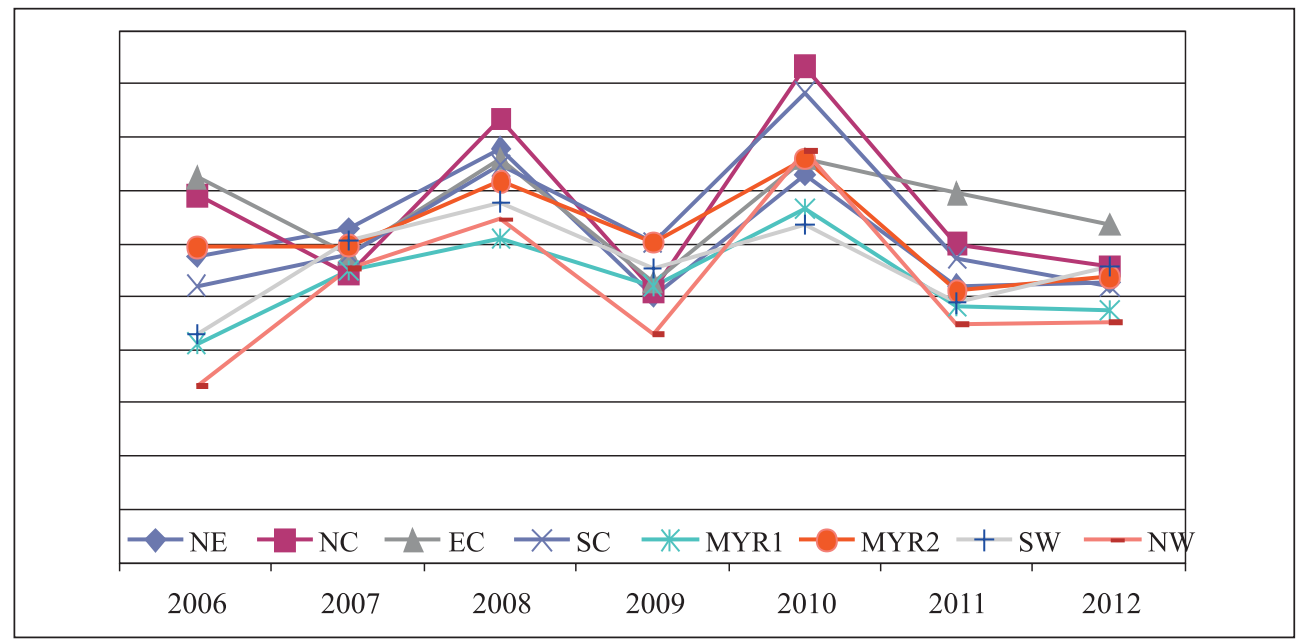

Source: Authors' calculation

Technical efficiency changes of 8 regions under environmental constraints are shown in Figure 5. The southwest region and the midstream of the Yellow River with relatively lower green TFP and technical progress rate showed higher technical efficiency than other regions.

Figure 5: Technical efficiency changes of 8 regions under environmental constraints

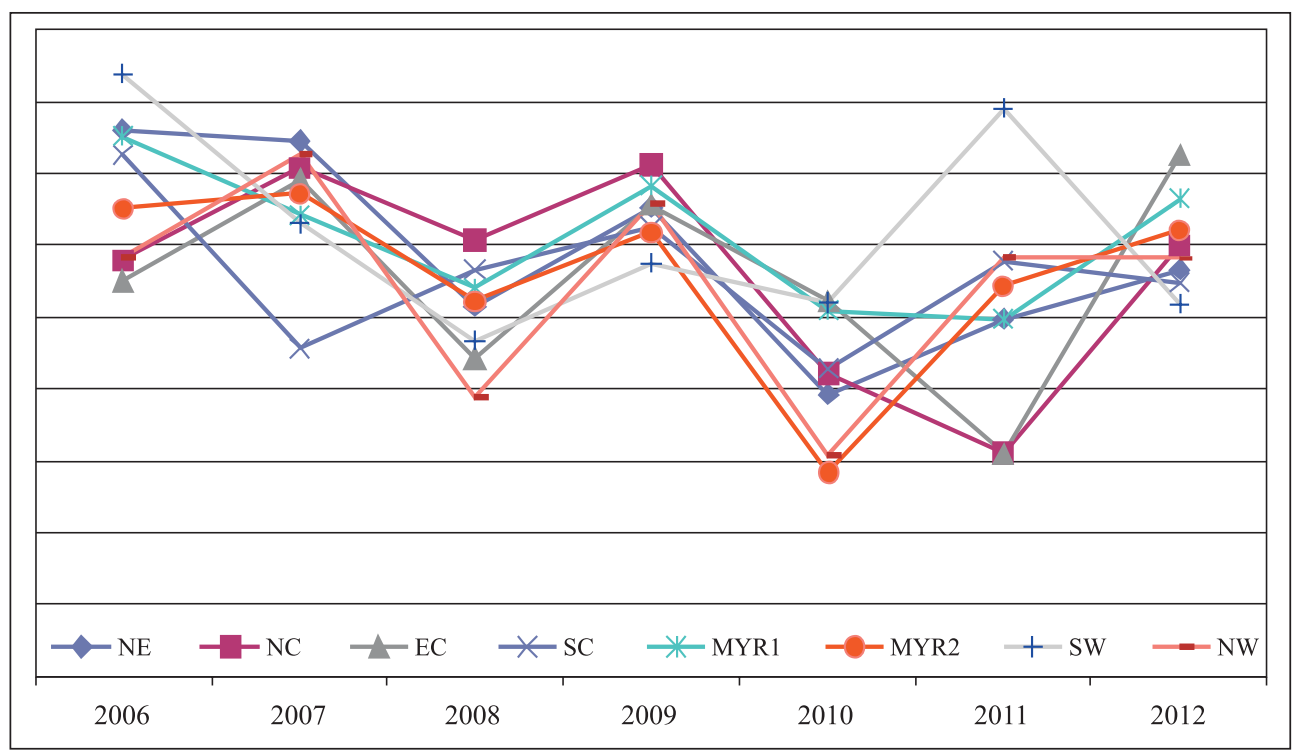

Source: Authors' calculation 
The southwest region achieved the highest annual average growth rate $(0.36 \%)$ and the midstream of the Yellow River achieved the second highest annual average growth rate $(0.23 \%)$. The rest six regions showed different degrees of technical efficiency reduction. The annual average technical efficiency reduction the northeast China was $-0.24 \%,-0.78 \%$ of the northern coastal region, $-0.79 \%$ of the southern coastal region, $-0.86 \%$ of the middle reach of the Yangtze River, $-0.91 \%$ of the eastern coastal region and $-1.1 \%$ of the northwest region.

The overall annual average growth rates of technical efficiency of 8 regions were similar with each other, indicating that technical progress is the main cause of green TFP difference among 8 regions.

\subsection{Empirical analysis on influencing factors of urban green TFP}

To avoid multicollinearity among variables, we gave a correlation analysis on the variables. The results showed that the economic density (eco) had a higher correlation with other variables. For example, with technical input, the correlation value was 0.595 . The correlation coefficient value of human capital (hum) and infrastructure (ins) was 0.614 . In order to avoid error results by multicollinearity, we removed the two variables of economic density (eco) and human Capital (hum). In order to guarantee the reliability of test results, this paper adopted random effects and fixed effects two kinds of models. By comparing, we can find the regression results for main explanation variables are consistent with the two kinds of methods. The model results are relatively stable. And the explanatory variables influencing on the green TPF are roughly the same direction. The traditional static panel data model may face the endogenous problem among variables. In order to eliminate endogenous problem leading the error, this paper further uses a Generalized Method of Moments (GMM) dynamic panel data. Sargan test indicated that the instrumental variable selection was effective; the probability value of coefficient is 0.000 , which indicated that the model is highly significant. The correlation test values of residual second-order serial for AR $(2)=0.258$, which proved that there was no correlation between the sequences. The estimated results were consistent in both static and dynamic panel, which further indicated that the selection of variables was reasonable and the model was robust.

Regression results of explanatory variables on green TFP of 285 cities are listed in Table 2. It can be seen that $\mathrm{adR}^{2}=0.714$, indicating the goods equation fitting effect. Viewed from regression coefficients of variables, all variables passed test on the $10 \%$ significance level. per-capita urban road area, environmental regulation, number of Internet users, proportion of fiscal expenditures, environmental regulation level and technical input are significantly positively correlated with green TFP, agree with our expectation. On the contrary, industrial structure and FDI cause significantly negative impacts on variation of green TFP. 
Table 2: Regression results between the Malmquist-Luenberger productivity index and related influencing factors

\begin{tabular}{|l|c|r|r|r|r|r|c|}
\hline Variables & $\begin{array}{c}\text { Fixed } \\
\text { effects }\end{array}$ & $\begin{array}{c}\text { Random } \\
\text { effects }\end{array}$ & $\begin{array}{c}\text { Generalized } \\
\text { Method of } \\
\text { Moments }\end{array}$ & Variables & $\begin{array}{c}\text { Fixed } \\
\text { effects }\end{array}$ & $\begin{array}{c}\text { Random } \\
\text { effects }\end{array}$ & $\begin{array}{c}\text { Generalized } \\
\text { Method of } \\
\text { Moments }\end{array}$ \\
\hline Ln(tfp) $)_{\mathrm{t}-1}$ & & & $1.085^{* *}$ & & & & \\
\hline $\mathrm{C}$ & $-17.035^{* * *}$ & $-10.82^{* * *}$ & & $\mathrm{Ln}(\mathrm{str})$ & $-1.933^{* * *}$ & $-0.745^{* * *}$ & $-2.100^{* * *}$ \\
\hline $\mathrm{Ln}(\mathrm{road})$ & $0.366^{* * *}$ & $0.264^{* * *}$ & $0.204^{* *}$ & $\mathrm{Ln}(\mathrm{fis})$ & $1.007^{* *}$ & $1.585^{* * *}$ & $0.663^{* *}$ \\
\hline $\mathrm{Ln}(\mathrm{int})$ & $0.302^{* *}$ & $0.359^{* * *}$ & $0.351^{* *}$ & $\mathrm{Ln}(\mathrm{env})$ & $0.039^{*}$ & $0.144^{* *}$ & $0.056^{*}$ \\
\hline $\mathrm{Ln}(\mathrm{fdi})$ & $-0.067^{* *}$ & $-0.103^{* * *}$ & $-0.055^{* * *}$ & $\mathrm{Ln}(\mathrm{tec})$ & $0.374^{* * *}$ & $0.491^{* *}$ & $0.147^{* *}$ \\
\hline & $/$ & $/$ & $/$ & \multicolumn{2}{|r}{$\mathrm{adR}^{2}=0.714$} & $\begin{array}{c}\mathrm{adR}^{2}= \\
0.546\end{array}$ & $\begin{array}{c}\text { Sargan test } \\
=0.380\end{array}$ \\
\hline
\end{tabular}

Note: ${ }^{* * *},{ }^{* *}$ and ${ }^{*}$ mean passing the test on the significance level of $1 \%, 5 \%$ and $10 \%$.

Source: Authors' calculation

According to analysis, proportion of the secondary industry increased obviously during the long-term rapid economic development in different regions. The accelerating industrialization that adopted the high input, high output and high pollution pattern intensified environmental protection pressure, which was against green TFP growth. Therefore, proportion of the secondary industry is negatively correlated with green TFP, which is in accordance with the research conclusion of Li Xiaosheng et al. (2014). Meanwhile, FDI causes significantly negative impact on green TFP, which supports the "Pollution Haven" hypothesis. This demonstrates that given low environmental regulation in China, abundant FDI flew into industrial sectors, especially high-pollution departments, thus hindering green TFP growth significantly. This also reveals that with China's economic transition development, it shall further enhance environmental regulation on FDI rather than adopting the "accepting everything" policy. Sort management of foreign investment is necessary. To improve overall FDI quality, foreign investments with high technical content and low pollution shall be introduced positively, while those with high pollution and energy consumption shall be restricted.

\section{Conclusion}

Research conclusions confirm our hypothesis that when pollution output is considered in the TFP analysis framework, urban TFP in China has declined significantly, $1.3 \%$ every year in average. This shows that traditional urban TFP in China was overestimated and China's rapid urban economic growth was achieved at the cost of environmental pollution. Due to the long-term imbalanced regional economic development, urban green TFP shows distinct regional differences in 
China. Per capita urban road area, number of Internet users, proportion of fiscal expenditures, environmental regulation level and technical input are significantly positively correlated with green TFP, while industrial structure and FDI cause significantly negative impacts on green TFP. From the obtained results, some contributions for the economic science are as follows: the green TFP of main cities in China are estimated more accurately by using big macroeconomic data, meanwhile, it discloses resources and environmental issues during the rapid urbanization, and provides good scientific support to future researchers on China's urban problems. However, there have been certain limitations for conducting this research. Different cities present different variations of green TFP and influencing factors, which is related with their significant differences in size, economic level, resource environment and geographic positions. We only analyzed the overall green TFP of 285 cities in China, but didn't divide studying cities into different groups. In addition, in our future research, we plan to divide China's cities into different groups by establishing an evaluation index system to explore variations and influencing factors of green TFP of different types of cities. Based on research conclusions, some suggestions are put forward. Firstly, China's traditional industrial growth pattern came to the end and Chinese government economic policy must change the original development pattern in order to maintain sustainable economic growth. It should shift economic dependence from inputs to TFP growth, especially green TFP growth. Secondly, Chinese government economic policy shall take the initiative to develop high-end equipment manufacturing, enhance core competitiveness of China's manufacturing industry, drive optimization and upgrading of industrial structure, accelerate merging and reorganization of high-pollution industries with surplus productivity (e.g. steel and cement), and realize transition from traditional industrialization depending on scale growth to new industrialization mainly depending on technical progress and sustainable development. Thirdly, a great attention should be paid to the cost of resources and environmental issues in economic development, investments to increase environmental pollution control, and enhance environmental pollution prevention and control. Governments set policies to facilitate transfer and diffusion of advanced environmental protection technologies among different regions, and improve environmental protection technologies in less developed areas. Fourthly, environmental regulation measures should be implemented continuously. Government should make a full play of market competitive advantages, integrating resources and elements of nonpollutant industries, while closing down enterprises with outdated technologies, high energy consumption and high pollution, as well as encourage development of large enterprises with state-of-the-art technology, low-level pollution and goods of economic efficiency. Fifthly, increasing environmental admittance threshold of foreign-funded enterprises, emphasizing on quality and structure of foreign capital introduction and enhancing environmental regulations to foreign-funded enterprises should become an important aspect to shift the idea of China's investment attraction under the perspective of sustainable development. 


\section{References}

Branchi, P. E., Fernandez-Valdivielso, C., Matias-Maestro, I. R. (2015) "Methodology to Assess The Impact of The Introduction of New Technologies on Smart Cities", Dyna, Vol. 90, No. 3, pp. 285-293, doi: 10.6036/7388.

Chambers, R. G., Faure, R., Grosskopf, S. (1996) "ProductivityGrowth in APEC Countries", Pacific Economic Review, Vol. 1, No. 3, pp. 181-190, doi: 10.1111/ j.1468-0106.1996.tb00184.x.

Chung Y. H., Fare R., Grosskopf, S. (1997) "Productivity and Undesirable Outputs: A Directional Distance Function Approach", Journal of Environmental Management, Vol. 51, No. 3, pp. 229-240. doi: 10.1006/jema. 1997.0146.

Fare, R., Grosskopf, S., Noh, D. W., Weber, W. (2005) "Characteristics of a Polluting Technology: Theory and Practice", Journal of Econometrics, Vol. 126, No. 2, pp. 469-492, doi: 10.1016/j.jeconom.2004.05.010.

Fare, R., Grosskopf, S., Pasurka C. A. (2007) "Environmental Production Functions and Environmental Directional Distance Functions", Energy, Vol. 32, No. 7, pp. 1055-1066, doi: 10.1016/j.energy.2006.09.005.

Fare, R. et al. (1994) "Productivity Growth, Technical Progress, and Efficiency Change in Industrialized Countries", The American Economic Review, Vol. 84, No. 1, pp. 66-83.

Kuang, Y., Peng, D. (2012) "Analysis of Environmental Production Efficiency and Environmental Total Factor Productivity in China", Economic Research Journal, Vol. 47, No. 7, pp. 62-74.

Li, X., An, Q. (2012) "Study on the Environmental Regulation Cost and Environmental Total Factor Productivity", The Journal of World Economy, Vol. 35, No. 12, pp. 23-40.

Li, X., Yu, Z., An, Q. (2014) "Influencing Analysis on Chinese Provincial Environmental Total Factor Productivity", China's Population Resources and Environment, Vol. 24, No. 10, pp. 17-23.

Managi, S., Ranjan, J. P. (2008) "Environment Productivity and Kuznets Curse in India", Ecological Economics, Vol. 65, No. 2, pp. 432-440, doi: 10.1016/j. ecolecon.2007.07.011.

Pan, D., Ying, R. (2012) "Spatial-temporal Differences of Agricultural Total Factor Productivity, Restudy of Previous Literatures", Economic Geography, Vol. 32, No. 7, pp. 113-118.

Wang, B., Wang, L. (2010) “An Empirical Study on Industry Technical Efficiency and Total Factor Productivity and Its Determinants under Environmental Constraint in China's Regional Economies", South China Journal of Economics, No. 11, pp. 3-19, doi: 10.3969/j.issn.1000-6249.2010.11.001. 
Wang, B., Yang H., Zhu, N. (2011) "Agricultural Efficiency and Total Factor Productivity Growth in China's Provincial Economies", South China Journal of Economics, No. 10, pp. 12-26.

Wang, J. H., Hsu, J. L. (2014) "Effects of Service Innovation on Oral Spreading and Consumption Intention in Catering Industry", Revista de Cercetare si Interventie Sociala, Vol. 47, pp. 220-232.

Wu S. B. (2016) "Cooperative R\&D Contract of Supply Chain Considering the Quality of Product Innovation", International Journal of Simulation Modelling, Vol. 15, No. 2, pp. 341-351, doi: 10.2507/IJSIMM15(2)CO7.

Wu, J. (2009) "TFP Growth and Convergence across China's Industrial Economy Considering Environmental Protection", The Journal of Quantitative \& Technical Economics, Vol. 26, No. 11, pp. 18-28.

Xue, J., Li, B. (2011) "Environmentlly-Adjusted Measurement of China's Agricultural Total Factor Productivity", China's Population Resources and Environment, Vol. 21, No. 5, pp. 113-118.

Yang, R. (2015) "Study on the Total Factor Productivity of Chinese Manufacturing Enterprises", Economic Research Journal, Vol. 50, No. 2, pp. 61-74.

Yuan, D., Lei, H., Huang, W., He, Y.. (2015) "Research on the Heterogeneity and Convergence of Total Factor Productivity in Chinese Producer Service", Soft Science, Vol. 29, No. 6, pp. 24-27, doi: 10.13956/j.ss.1001-8409.2015.06.06.

Zhang, J., Kopytov, C., Mou, Q. (2014) "Study on the change and regional differences about total factor productivity considering the environmental pollution in China", Nature Environment and Pollution Technology, Vol. 13, No. 2, pp. 327-332.

Zhong, Y. (2015) "The Effect of Patent on Productivity Growth in China", Science \& Technology and Economy, Vol. 28, No. 6, pp. 42-46, doi: 10.14059/j.cnki. cn32-1276n.2015.06.010.

Zhu, H., Yang, X. (2013) "Fiscal Expenditure, Technology Selection and Economic Performance: An Empirical Study Based on Provincial Panel Data", Industrial Economic Review, Vol. 4, No. 6, pp. 88-96, doi: 10.14007/j.cnki. cjpl.2013.06.006. 
Studija o ukupnom faktoru zelene produktivnosti u glavnim gradovima Kine $^{1}$

\author{
Zhang Jiansheng ${ }^{2}$, Tan $\mathrm{Wei}^{3}$
}

\begin{abstract}
Sažetak
Cilj ovog istraživanja je ispitati kineski ukupan faktor 'zelene' produktivnosti (total factor productivity - TFP) u pozadini sve progresivnije urbanizacije i intenzivnijeg onečišćenja okoliša, te ustanoviti koji su glavni čimbenici koji utječu na to. U ovom radu, u periodu od 2005. do 2012. godine, zeleni TFP u 285 prefektura koje su na razini gradova u Kini, procijenjen je pomoću Malmquistova indeksa proizvodnosti. Rezultati pokazuju da godišnji rast zelenog TFP-a u glavnim gradovima u Kini iznosi 3,5\%, te da ukupni rast postupno opada. Gledano s aspekta dekompozicije zelenog TFP-a, ono što najviše doprinosi rastu zelenog TFP-a je tehnološki napredak. Osim toga, na sjevernom obalnom području postignut je najviši godišnji rast zelenog TFP-a (4,5\%) dok je u sjeverozapadnoj regiji ostvaren najniži rast zelenog TFP-a (1,24 \%), što ukazuje na velike regionalne razlike u zelenom TFP-u i kvaliteti gospodarskog rasta u Kini. Prema analizi čimbenika koji utječu na zeleni TFP u glavnim gradovima, zaključeno je da po glavi stanovnika na urbanom području uz prometnice, broj korisnika Interneta, udio proračunskih rashoda, razina regulacije okoliša i tehnički input imaju značajnu pozitivnu korelaciju sa zelenim TFP-em, dok zeleni TFP značajno negativno korelira $s$ industrijskom strukturom $i$ izravnim stranim ulaganjima (FDI). Na kraju, dani su prijedlozi za politiku poboljšanja urbanog zelenog TFP-a u Kini.
\end{abstract}

Ključne riječi: ukupan faktor zelene produktivnosti, Malmquist-Luenbergerov indeks produktivnosti, usmjerena funkcija udaljenosti, Kina

JEL klasifikacija: 013,018, Q56

1 Ovaj je rad nastao uz potporu National Social Science Foundation of China (No. 12XGL019).

2 Izvanredni profesor, College of Finance and Economics, Chongqing Three Gorges University, Chongqing 404120, Kina. Znanstveni interes: razvojna ekonomija, industrijska politika. Tel.: +8615923400592. E-mail: asheng0124@126.com (autor za korespodenciju).

3 Izvanredni profesor, College of Public Management, Chongqing Three Gorges University, Chongqing 404120, Kina. Znanstveni interes: industrijska politika. Tel.: +861582640 5802. E-mail:tanwei0524@126.com. 